\title{
The Unexpected Survival of Employer Collective Action in the United Kingdom
}

\author{
La survie inattendue de l'action collective des employeurs au \\ Royaume-Uni
}

\section{La inesperada sobrevivencia de la acción colectiva de los empleadores en el Reino Unido}

\author{
Philippe Demougin, Leon Gooberman et Marco Hauptmeier
}

Volume 74, numéro 2, printemps 2019

URI : https://id.erudit.org/iderudit/1062087ar

DOI : https://doi.org/10.7202/1062087ar

\section{Aller au sommaire du numéro}

Éditeur(s)

Département des relations industrielles de l’Université Laval

ISSN

0034-379X (imprimé)

1703-8138 (numérique)

Découvrir la revue

Citer cet article

Demougin, P., Gooberman, L. \& Hauptmeier, M. (2019). The Unexpected Survival of Employer Collective Action in the United Kingdom. Relations industrielles / Industrial Relations, 74(2), 353-376.

https://doi.org/10.7202/1062087ar

\section{Résumé de l'article}

De récentes recherches menées en relations de travail ont montré que les organisations collectives d'employeurs continuent leurs activités dans divers pays présentant des caractéristiques institutionnelles différentes. Au Royaume-Uni, nous avons recensé 447 organisations d'employeurs (OE) actives dans les domaines des relations de travail et de la gestion des ressources humaines. Ce grand nombre d'organisations a inspiré notre question de recherche: Qu'est-ce qui explique l'évolution du rôle et des activités des OE du Royaume-Uni?

Les études menées au niveau national sur le rôle des OE ont eu recours à une gamme de cadres théoriques pour analyser la manière dont ces organisations se sont adaptées dans le temps aux changements institutionnels et économiques, mais, le mode d'analyse le plus efficace fait toujours l'objet de débats. Dans cet article, notre contribution consiste à appliquer, à l'économie de marché libérale du Royaume-Uni, le cadre de Schmitter et Streeck qui identifie les logiques sous-jacentes régissant le comportement des OE, cela en utilisant le même cadre appliqué aux économies de marché coordonnées, telles que définies dans le cadre des études sur les "variétés du capitalisme ». L’article regarde dans quelle mesure la libéralisation a provoqué un nouveau comportement au sein des $\mathrm{OE}$.

Certaines études ont soutenu que, dans les économies de marché coordonnées, les $\mathrm{OE}$ vont s'adapter en accordant la priorité aux logiques liées au membership. Nous explorons comment l'évolution de l'économie politique britannique a entraîné une évolution dans l'application des logiques d'adaptation des OE et constatons que c'est plutôt l'inverse qui s'est produit. Par le passé, les OE privilégiaient plutôt une logique d'influence faisant appel à la participation des membres dans le cadre des négociations collectives face aux syndicats ainsi que pour oeuvrer au sein d'organismes institutionnels tripartites, mais ces institutions se sont effondrées. On aurait pu s'attendre à ce que cette dégradation se traduise par le dépérissement des OE, mais elles se sont plutôt réorganisées. La diminution de l'importance de la logique d'influence a incité les organismes d'employeurs à se concentrer davantage sur la logique du membership en proposant une gamme plus large de services destinés aux membres. Nos résultats indiquent que les $\mathrm{OE}$ peuvent réagir à la libéralisation par une adaptation, cela afin d'éviter l'extinction. Enfin, nous croyons que notre méthodologie pourrait servir à éclairer le comportement des OE en Amérique du Nord.
Tous droits réservés (C Département des relations industrielles de l’Université Laval, 2019
Ce document est protégé par la loi sur le droit d'auteur. L’utilisation des services d’Érudit (y compris la reproduction) est assujettie à sa politique d'utilisation que vous pouvez consulter en ligne.

https://apropos.erudit.org/fr/usagers/politique-dutilisation/ 


\title{
The Unexpected Survival of Employer Collective Action in the United Kingdom
}

\author{
Philippe Demougin, Leon Gooberman and \\ Marco Hauptmeier
}

The study of employer collective organizations has been revitalized recently but the most effective mode of theoretical analysis is debated. This article applies Schmitter and Streeck's competing logics of membership and influence framework to employer organizations in the United Kingdom. While literature using this framework argues that employer collective bodies are likely to prioritize the logic of influence by influencing the state through partnering with governments, we find that the opposite happened in the United Kingdom. Changing political economy meant that the logic of influence decayed in salience although did not disappear. Employer organizations prioritized instead the logic of membership to ensure survival.

KEYWORDS: employer organizations, collective action, employer interest representation, employment relations, United Kingdom.

\section{Introduction}

The study of Employer Organizations (EOs) has been neglected by the employment relations literature (Barry and Wilkinson, 2011). Analysis of EOs has been subsumed within that of collective bargaining, with reducing levels of bargaining assumed to have undermined EOs' reason for existence against a backdrop of marketization (Baccaro and Howell, 2017; Streeck, 2009). However, recent studies (e.g., Ibsen and Navrbjerg, 2018; Behrens and Helfen, 2016; Sheldon et al., 2016; You and Barry, 2016; Zhu and Leyland, 2017; Gooberman, Hauptmeier, and Heery, 2017, 2018, 2019a, 2019b) demonstrated that employer collective organizations continue to thrive in countries featuring different institutional characteristics. These and other studies ensured that the "strange non-death of employer and business associations" (Brandl and Lehr, 2016:1-22) emerged as a focus of analysis within employment relations.

Philippe Demougin, Doctoral Researcher, Cardiff Business School, Cardiff University, Cardiff, South Wales, United Kingdom (demouginpr@cardiff.ac.uk).

Leon Gooberman, Lecturer in Employment Relations, Cardiff Business School, Cardiff University, Cardiff, South Wales, United Kingdom (goobermanLM@cardiff.ac.uk).

Marco Hauptmeier, Professor of International Human Resource Management, Cardiff Business School, Cardiff University, Cardiff, South Wales, United Kingdom (hauptmeierm@cardiff.ac.uk). 
Studies of 'non-death' use many theoretical frameworks to analyze how EOs have adapted to institutional and economic change, but the most effective mode of analysis is debated. In particular, any one theoretical framework has yet to be applied across coordinated and liberal market economic types of national systems as defined by 'Varieties of Capitalism' (Hall and Soskice, 2001). Our contribution applies Schmitter and Streeck's (1999) identification of logics driving the behaviour of employer collective organizations, previously applied to coordinated market economies, to the United Kingdom's (UK) emblematic liberal market economy. The article explores the extent to which liberalization within liberal and coordinated market economies prompted new behaviour within employer collective bodies, developing a methodology that could shed light on EOs behaviour in North America.

We use two datasets to identify and analyze EOs in the UK. One is a database of 447 membership-based EOs active within employment relations and human resource management (HRM). The other is 98 interviews of EOs representatives, as well as those of associated bodies such as trade unions and governments. The volume of organizations identified prompts our research question: What explains the changing role and activities of UK EOs?

Schmitter and Streeck (1999) identified four logics shaping the behaviour of employer collective organizations. The workings of these logics within an EO implies that goals and policies are shaped by: the interests of the membership; its own capacity and resources; what is expedient within the political process; and, its mode of internal decision making. When the employment relations literature uses the logics approach to examine employer collective action in coordinated market economies (e.g., Behrens, 2018), the four logics are combined and summarized to the dual logics of membership and influence.

Lang et al. (2008) and Traxler (2007) argued that EOs in some coordinated market economies adapted by prioritizing logics driving influence over those linked to membership. We explore how the UK's changing political economy spurred evolution in the application of these logics and find that the opposite has happened. EOs once used participation within collective bargaining agreements and the governance of tripartite bodies to prioritize the logic of influence, but these institutions decayed (Baccaro and Howell, 2017). It might have been expected that such decay would have caused a withering of EOs, but they reconstituted themselves instead. The declining salience of the logic of influence prompted employer bodies to focus to a greater degree on the logic of membership by offering a broader range of member focused services. Our findings indicate that employer collective bodies react to liberalization with adaptation, not extinction. Similar trends may also be observed in coordinated market economies undergoing some decentralization. For example, an increasing number of EOs in Germany 
offer 'bargaining-free' membership to employers seeking to access services without participation in collective agreements (Behrens and Helfen, 2019).

The remainder of this article is structured as follows. We first review the literature and outline the two logics approach. Second, we present our methodology, data sources and an overview of contemporary EOs. Third, we apply the two logics approach to UK EOs before 1979 to provide a baseline for comparison, deriving two propositions as to how EOs adapted to change. Fourth, we apply the dual logic approach to contemporary EOs. Finally, we analyze how EOs have successfully reconciled the impacts of both logics over time, before concluding.

\section{Explaining employer collective action}

EOs have been a neglected subject within the employment relations literature (Barry and Wilkinson, 2011; Brandl and Lehr, 2016). Much of this neglect was attributable to the conflation of employer collective action with collective bargaining. Such conflation meant that the decline of bargaining and the growth of marketization (Baccaro and Howell, 2017; Streeck, 2009) was interpreted as catalyzing a parallel reduction in collective employer action. UK focused studies that mention EOs (e.g., Simms, 2017) consider them as an aside to analysis of trade unions. However, recent years have seen a reappraisal of EOs and their survival emerged as a research topic. Brandl and Lehr (2016) studied employer collective bodies across Europe, arguing that "rather than being a relic, [they] have adjusted and remain alive and kicking" (2016: 19), characterizing survival as the "strange non-death of employer and business associations". Two strands can be identified within the 'strange non-death' literature.

One strand focuses on the provision of new selective incentives and the role of institutional entrepreneurs in helping EOs survive lessening volumes of collective bargaining through organizational adaptation and innovation. Ibsen and Navrbjerg (2018) used functional and structural adaptation (Traxler, 2004) to explain change in Danish EOs, finding that they layered (Streeck and Thelen, 2005) new services onto traditional collective functions. Layering was driven by changes within employment relations and although survival was linked to the continuation of some collective approaches, the provision of such goods within bargaining was insufficient to ensure EOs' survival. This dynamic forced EOs to offer new services focusing on individual firms. Sheldon et al. (2016) used strategic choice and resource dependency to analyze Australian EOs as organizations facing potential environmental threats to their financial sustainability, arguing that bargaining decentralization increased exposure to competition and produced responses prioritizing commercial over associational objectives. The importance of commercial objectives, in the shape of intra-industry competition, in driving change was also highlighted by You and Barry's (2016) study of Australian retail EOs. 
The other strand focuses on the external pressures impacting employers. Barry and Wilkinson (2011) called for the reconceptualization of countervailing power (Galbraith, 1952) as an explanatory concept within employer collective action. Gooberman, Hauptmeier, and Heery (2019b) applied countervailing power to the UK and argued that, as opportunities for EOs to countervail against organized labour reduced, opportunities arose to respond to social movements and state regulation. Zhu and Nyland (2016) fused countervailing power with institutional complementarity (Crouch et al., 2005) when analyzing EOs in China to argue that an inability to countervail against social partners explained the trajectory of a leading organization.

As well as the two strands described above, Behrens and Helfen (2016) conceptualized German EOs as meta-organizational (Arne and Brunson, 2005) field-level governing bodies acting as 'ideational brokers' central to structuring employment relations. The analysis used political and organizational institutionalism to argue that, while adherence to social partnership norms remained strong across EOs, this was increasingly contested. Finally, Behrens (2016) analyzed German EOs through combining the dual logics approach with a meso-level perspective of organizational rules, highlighting how sets of rules existed to protect members' interests. Rules blocked EOs' access to confidential business information enabling them to continue prioritizing the logic of membership over that of influence.

Arguments integral to the first strand, with their focus on organizational motives, may be considered as contradicting those in the second, with their emphasis on external environmental factors. However, it is equally possible to argue that both complement each other in that the external factors identified in the second strand combine to create the organizational innovations outlined in the first. Against this background, two factors prompt our use of the two logics approach. One is that such usage may enable the analytical gap between the two strands to be bridged by providing clearer linkages between external circumstances and organizational reaction. The other is that any one theoretical frame has yet to be applied across coordinated and liberal market economies. We contribute to the 'strange non-death' debate by examining the extent to which Schmitter and Streeck's (1999) seminal study of interest representation, used within coordinated market economies (e.g., Behrens, 2018), can be applied to the liberal market economy of the UK.

\section{Explaining employer collective action - the two logics}

Schmitter and Streeck's (1999) study outlining their logics approach addressed contradictions within employer collective action caused by free rider problems (Olson, 1965) in that a successful EO is one that mobilizes collective solidarity in 
the competitive pursuit of individual interests. It drew on Child, Loveridge, and Warner's (1973) paper on union organization to argue that the organization of employer interests is shaped by four logics. First, the logic of membership requires EOs to organize their structure and activities in a manner that incentivizes members to supply the organization with resources. The second logic of influence implies that EOs need to influence the state to obtain concessions or resources for itself, its members or both, as explored by Martin and Swank's (2012) analysis of collective action. Importantly, an EOs' ability to influence the state depends in part on its ability to demonstrate its utility as an interlocutor by displaying specialized knowledge and a credible degree of representativeness. The third logic, of goal formation, reflects EOs' decision making, with approaches ranging from decisions being taken solely by the leadership to those where members wield influence through democratic structures. The final logic is efficient implementation which argues that EOs need to combine organizational efficiency with the safeguarding of social and economic capital.

The workings of these four logics within an EO implies that goals and policies are shaped by: 1- the interests of the membership; 2- its capacity and resources; 3- what is expedient within the political process; and, 4- its mode of internal decision making. However, when the employment relations literature uses the logics approach to examine employer collective action within coordinated market economies (e.g., Behrens, 2018), the four logics are combined and summarized as dual logics of membership and influence.

Two tensions exist within the dual logics. One is that an EO's appeal to its members may be increased if the state entrusts it with regulatory tasks or policy implementation, implying that the state drives associability (Lang et al., 2008). This process implies that EOs may transform away from their emphasis on promoting member interests towards being 'quasi-authorities', enacting rules to bind all members (Traxler, 2007; Schmitter and Streeck, 1999). The other tension appears within the governance of EOs, where the two logics interact to produce dualistic leadership structures (Schmitter and Streeck, 1999). Such structures typically include a member-elected chair and democratically constituted bodies to provide strategic leadership, while a professional administrator oversees operational matters. The dualist approach creates organizational tensions between both logics. Elected part-time leaders may be closer to their membership and hence seek consensus, while professional managers might aim to secure long-term funding security through providing authoritative goods and selling compliance to government. Schmitter and Streeck (1999) proposed that such tensions are reconciled by sacrificing the ability of members to influence EOs through democratic governance systems. Reducing the internal power of members ensures greater organizational effectiveness, making EOs more attractive to current and potential members. 
Overall, both tensions are defused by EOs prioritizing the logic of influence over that of membership and acting as "established interest governments" (Schmitter and Streeck, 1999: 93). Such an EO becomes a 'quasi-authority' where members are given the impression of participation but decision-making power is centralized. However, a recent study of EOs in Germany (Behrens, 2018) found instead that they used their dualist structures to grant members the ability to take part in the associations' decision-making process, thus balancing both logics. This finding supports Traxler's (1999) arguments as to the improbability of employer members agreeing that their influence over decision making within EOs should be exchanged for ongoing membership as members can leave and regulate employment relations independently. Finally, the granting by EOs of decision-making powers to their members has some similarities to the efforts made by unions to drive greater involvement of their members within decision-making processes (e.g., Heery, Kelly, and Waddington, 2003).

Can the dual logics framework be applied to address our research question: What explains the changing role and activities of UK EOs? A recent study (Gooberman, Hauptmeier, and Heery, 2019a) argued that the structure and activities of EOs have been transformed as a result of broader changes within the UK's system of employment relations. Given this change, we examine the pre-1979 pattern of EOs representation and identify how the dual logics played out within this system. This examination produces a baseline for comparison with contemporary patterns of organization illustrated by our data, as outlined below.

\section{Data collection, and overview of UK EOs}

Accurate, official data on EOs in the UK do not exist. While the government's Certification Office annually produces lists of employer collective bodies, these have two weaknesses. The first is that the Certification Office focuses only on organizations active within collective bargaining, excluding others that provide services linked to HRM and employment relations. The other is that registration with the Certification Office is optional and there are no significant advantages linked to doing so. Given this lack of comprehensive data, we based our analysis on two other sources.

One source was our database of EOs. We initially prepared a long-list of some 2,400 organizations, using a web-based directory (Trade Association Forum, 2015), secondary sources, and practitioner interviews. We then used the individual websites of each longlisted organization to assess whether it met three criteria for inclusion in the database. The first was a membership base that is comprised predominantly of employers, or of individuals acting as employers. Second, members must pay subscription charges. The final criterion was activity in employment relations and HRM. Employment relations activity could include 
collective bargaining or providing related advisory services, while HRM activity could include training, or advising on health and safety, employment law and equality. We used these criteria to identify 447 organizations. We prepared 60 questions to be answered for each EO across: the membership composition; internal structure and governance arrangements; the nature of the activities and services provided to, and on behalf of, members; the extent and nature of the relationship with trade unions, as well as contact with government and its agencies. The database was populated primarily from EOs websites, but data were also gathered from sources such as the Certification Office and the parliamentary website (House of Commons, 2015). EOs used their websites to communicate with existing members, attract new members and inform the public. The potential for reputational damage implies that EOs were unlikely to persistently present false information.

The other source was 98 semi-structured interviews carried out with representatives of EOs and associated bodies such as unions, professional associations, civil society organizations and government. Interviews took place between 2013 and 2018 in person or via telephone with most lasting between 60 and 90 minutes. All were transcribed and pursued themes similar to those explored by the database. Interviews with EOs representatives were used to triangulate the findings of our database and provide greater empirical detail, while those with representatives of other organizations and government officials provided alternative perspectives on the role played by EOs within employment relations.

We identified 447 EOs in the UK. Data on membership numbers were available for 357 EOs and these had a total membership of over 750,000 employers. The median number of members was 170, with membership of individual EOs ranging from 6 to 195,000. The largest EOs were either peak organizations that drew their membership from across industries and regions, or those that represented parts of the economy characterized by a large volume of small businesses. Peak organizations included the Federation of Small Businesses (c. 195,000 members), the Confederation of British Industry (c. 190,000 members) and the British Chamber of Commerce (c. 104,000 members).

Membership of all EOs was aimed at employers, or individuals acting as employers. The distinction between employers, individuals acting as employers and individuals was often blurred, but some organizations allowed individual membership. These operated within the overlap between professional organizations and EOs, often within sectors where self-employment was common. Other EOs restricted full membership to companies, but allowed individuals to join as associates. Seventeen organizations accepted other EOs as members. These were often federated organizations, providing a mixture of centralized managerial and service-related functions to their autonomous members. Finally, we identified 
EOs' industrial foci by allocating each to a standard industrial classification code. The largest proportions were in manufacturing (14 per cent), wholesale and retail trades (13 per cent), and construction (12 per cent). The overwhelming majority of EOs focused on one industry.

\section{Changing logics in the UK}

EOs had two primary activities before the UK's system of employment relations changed after the 1979 election of Margaret Thatcher's Conservative Government. One activity was representing employer interests within national multiemployer bargaining structures, although some weakening was apparent (Emmenegger, 2014). The other was participating in the governance of tripartite bodies involved in economic and labour market governance (Gospel, 2012; Crouch, 1979). Such bodies included those setting industry specific minimum wages, controlling the vocational training system, and advising governments on incomes policy.

Participation within bargaining structures enabled EOs to act as interlocutors, while jointly governing tripartite bodies enabled EOs to deliver benefits to their membership by exercising power delegated from the state. The corporatist approach that characterized employment relations and created these institutions enabled EOs to prioritize the logic of influence, generating collective goods of benefit to their membership. As a result, EOs did not need to pro-actively organize their structure and activities to incentivize members to supply the organization with resources, as implied by the logic of membership.

However, EOs were pushed to the margins of policy making after 1979 by a more assertive mode of government and their two primary activities reduced dramatically in scope and scale. Proportions of employees covered by collective bargaining fell from 70 per cent in 1984 (Brown, Bryson, and Forth, 2008) to 23 per cent in 2011 (Van Wanrooy, Bewley, and Bryson, 2013). Most of the tripartite bodies jointly governed by EOs were abolished or downgraded, including those covering wages and training (Gospel, 2012). These changes were a key factor driving an 81 per cent fall in the number of collective bargaining bodies registered with the government's Certification Office between 1976 and 2013-2014 as such bodies either closed or refocused their activities (Gooberman, Hauptmeier, and Heery, 2019a).

How did EOs adapt to survive changing political and economic circumstances? We propose that these changing circumstances spurred EOs to amend their foci and activities, reducing those linked to the logic of influence and increasing those linked to the logic of membership, to ensure that they can continue to create value for their members. We identify two propositions for testing against our 
data. First, the nature of contemporary employment relations in the UK, often considered as an emblematic liberal market economy, precludes usage by EOs of the logic of influence as proposed by Schmitter and Streeck (1999). EOs would not make substantial efforts to influence the state through forming regulatory or operational partnerships, representing member interests instead through lobbying and other activities. Second, EOs would adapt to the decline of collective bargaining and tripartite structures by prioritizing member-focused services that would incentivize members to participate in collective action. EOs would also retain democratic structures to create a sense of ownership amongst members, and ensure that they can represent their industry through articulating concerns accurately. We now examine our data on contemporary EOs to test these two propositions.

\section{Exploring the logic of influence}

To address successfully the logic of influence, EOs must effectively represent their members' interests within the political system. But all political systems contain different channels of influence, each offering opportunities and pitfalls for EOs. In general, the logic of influence rests on an "exchange relationship" (Schmitter and Streeck, 1999: 31) where EOs acquire organizational properties that enable them to exploit the authority, interests and needs of the actors they influence for their own purposes to ensure survival.

In this section, we gauge the extent to which EOs can create and exploit exchange relationships by analyzing approaches that they used to influence political affairs through: lobbying governments; influencing employer behaviour through joint regulation through government bodies; and, collective bargaining.

\section{Lobbying governments}

EOs occupy a special position in the logic of influence in liberal market economies such as the UK. Although collective institutions have decayed in terms of their incidence and influence within employment relations, governments actively regulate the economy and labour market, offering opportunities for EOs to build relationships and exert influence to represent their members' interests. Our data demonstrated that 327 (73 per cent of all EOs observed) lobbied governments. An example was the British Retail Consortium (BRC) whose representative stated that "a very significant amount of what we do is around a government-influencing agenda or influencing other public agencies" (Interview with BRC representative, 28/6/2017). They aimed to persuade central and devolved governments to adopt policies more in line with members' collective interests, but there was no element of exchanging such policies with enforcing membership compliance. 
EOs used a range of formal and informal techniques to lobby governments on issues related to employment relations. Formal activities included issuing policy statements and proposals for changing laws and regulations; responding to consultations, participating in single issue advisory groups convened by the government, or appearing before subject committees of the House of Commons, House of Lords or devolved institutions. Relationships between individual EOs and the government exhibited a mix of formal and informal approaches, as illustrated by a representative of Employers for Carers (EfC):

We produced a Memorandum of Understanding with the government in March 2010 [...] Department of Health co-ordinated it, but it had BIS [Department for Business. Innovation and Skills] as it was then, DWP [Department for Work and Pensions], Communities and Local Government [...] Education and Government Equalities Office, which set out the scope and direction of working in partnership. So it was like a sort of Memorandum of Understanding about what we would aim to do [...] supporting working carers (Interview with EfC representative, 2/8/2016).

Empirical data on the occurrence, if not the effectiveness, of one type of formal lobbying were available from the committee sections of the House of Commons' website (House of Commons, 2016). These identified 140 EOs (31 per cent of those observed) questioned by MPs' committees over the preceding decade. The topics on which they were questioned covered a vast range, illustrated by a representative of the Federation of Small Businesses (FSB) stating that they appeared before "Select Committees, Public Bill Committees, that sort of thing [...] we'll give all our evidence [...] labour market, education and skills [...] tax, infrastructure, finance, all these issues" (Interview with FSB representative, 2/3/2015). However, accurate quantitative data on informal lobbying were difficult to identify given that sustaining political relationships depends on informal and private communication, but many interviewees (e.g., National Farmers' Union, Business Disability Forum) discussed the importance of informal approaches.

Exchange relationships' impacts on EOs' organizational structures were reflected by variations in their geographical coverage and headquarter locations. Most EOs had broad geographical coverage, with 371 (83 per cent) of those observed accepting members from all parts of the UK. However, the UK's relatively centralized political system meant almost half of EOs were headquartered in or around London (see Table 1), including active and high-profile lobbyists such as the Engineering Employers' Federation or the British Retail Consortium.

Nevertheless, the creation of devolved political institutions in Scotland, Wales and Northern Ireland over the past two decades spurred more EOs activity at sub-UK levels. Opportunities to create exchange relationships were increasingly important as powers accrued to devolved institutions, while the small scale of linked civil societies meant that such institutions were more accessible. As exam- 


\begin{tabular}{|c|c|c|}
\hline \multicolumn{3}{|c|}{ Headquarters location of EOs } \\
\hline Region & Number & $\%$ of total \\
\hline London and South East England & 218 & 49 \\
\hline Other England & 173 & 39 \\
\hline Scotland & 34 & 8 \\
\hline Wales & 11 & 2 \\
\hline Northern Ireland & 11 & 2 \\
\hline
\end{tabular}

ples, a representative of the FSB Northern Ireland noted how devolution "drove the need for the FSB to set up its own policy unit within Northern Ireland to focus on policy work and engagement with the emerging Assembly" (Interview with FSB NI representative, 3/6/2015), while a representative of CBI Wales noted the ease of access to politicians in a devolved context: "the last [CBI] Council meeting, the First Minister [of the Welsh Government] came" (Interview with CBI Wales representative, 13/06/2017).

The above evidence demonstrates the three avenues open to EOs when seeking to influence the state, reflecting "how organizations representing business interests tend to be prominently represented" (Schmitter and Streeck, 1999: 36). The first is formal lobbying, where both government and parliament invite EOs to become involved in the policymaking process. The second is informal lobbying, which is an increasingly important element of EOs' activity as it offers either the appearance or reality of privileged access to policy makers. The final avenue is lobbying at devolved levels, where the existence of new and increasingly powerful institutions is driving spatial fragmentation. EOs were always flexible in who and how they lobbied, and were prepared to switch priorities quickly to maximize the extent to which their members' interests were promoted. For example, CONFOR (the EOs representing the Scottish forestry industry) was once a subscribing member of a European level EOs lobbying in Brussels, but left and redirected resources elsewhere as the national interests represented by the European EOs were often different to those of a UK-based organization (Interview with CONFOR representative, 20/6/2017).

\section{Joint regulation through government bodies}

The UK's political system once featured a tradition of corporatist, often tripartite, bodies focused on aspects of labour market regulation such as training and minimum wage setting (Crouch, 1979). The governing boards of these bodies included representatives of EOs. While their incidence declined sharply in 
recent decades, some remained and a small number of new organizations were established. Survivors included the Advisory, Conciliation and Arbitration Service (ACAS), and the Health and Safety Executive. Bodies established in recent years included the Low Pay Commission to advice on the statutory minimum wage and the Gangmasters and Labour Abuse Authority. Although governments appointed EOs representatives to the boards of these four bodies, all but the first lacked discretionary responsibilities and were instead restricted to an advisory function. The exception was the ACAS, which could decide policy within its narrow remit of industrial conciliation. This relative lack of discretionary power means that the bodies on which EOs are represented are not comparable with the tripartite bodies that once existed, and the state has not used remaining bodies to devolve large-scale regulatory or market power to EOs.

\section{Collective bargaining}

Participation within collective institutional approaches to employment relations was limited to a small number of EOs. Only 59 organizations (13 per cent of those observed) were active within collective bargaining structures. Of these $59 \mathrm{EOs}, 43$ were formally involved within the governance of a joint agreement regulating employment conditions. Agreements included the Construction Industry Joint Council Working Rule Agreement, signed by nine EOs, the National Agreement for the Engineering Construction Industry, signed by three EOs, as well as those operating within the public sector. A representative of Employers for Voluntary Housing (EVH) noted that: "We've got a Joint Negotiating Committee which works with Unite the Union and we negotiate wages and terms and conditions with the Union and our full members are bound by those" (Interview with EVH representative, 22/06/2017).

Despite the continued existence of collective bargaining enabling EOs to negotiate terms and conditions of employment which members then implement, EOs' ability to utilize the logic of influence to retain members has been reduced by dilutions within bargaining. One is that the implementation of collectively agreed conditions was not always a condition of membership. For example, after 2000, members of the Electrical Contractors Association (ECA) were not obliged to join the joint industry board that regulated collective agreements negotiated by the ECA and the unions (Interview with ECA representative, 2/03/15). A second dilution was that collective approaches within the public sector often featured non-binding frameworks agreed between EOs and unions, as opposed to agreements that set out the pay and conditions that had to be followed (Interview with Association of Colleges representative, 7/10/2015).

While institutional collective approaches to employment relations expressed through collective bargaining or tripartite bodies remain important within parts 
of the UK labour market, the importance of such approaches decreased markedly over recent decades. A representative of the Retail Motor Industry Federation (RMIF) noted that:

We used to have what we called the NJC [National Joint Council] Agreement. It used to be made up of various representatives from the industry and would set the rates for mechanics [...] then we had Minimum Wage and Living Wage coming in from the Government anyway. So it basically became redundant (Interview with RMIF representative, 21/06/2017).

Changes such as those described by the RMIF spurred EOs to reorient their foci within employment relations. EOs focused increasingly on influencing the state and advising members on employment relations within a system that prioritized the importance of individual employment relationships.

\section{Exploring the logic of membership}

\section{Governance}

Child et al., (1973: 75) argued that members might consider an organization to be a commodity, and thus have little interest in participating in its internal processes. It could be expected that EOs would take advantage of such passivity by downgrading their democratic structures, thus creating greater autonomy for their professional leadership. However, a more active membership may enable the leadership to make a more persuasive case to government that they are truly representative of their industry and can articulate concerns accurately.

Our data demonstrated that EOs usually had a chair, a governing body and an annual general meeting. Of the EOs observed, 389 (87 per cent) provided details of their chair, responsible for non-executive leadership with day to day management carried out by a chief executive. Chairs tended to be appointed by the governing body, although some member-elected chairs did exist, such as those of the National Outdoor Events Association and the National Farmers' Union. Governance arrangements can be complex with, for example, the Ulster Farmers' Union (UFU) featuring a council of:

About four or five hundred members [who] vote for our Presidential Team [...] There'll be one President and two Deputy Presidents and they usually serve on a two-year term [...] We also have a Management Board [...] done at County level. We have a County Chairman and a Vice Chairman, and they would be responsible for putting people onto our Board (Interview with UFU representative, 4/6/15).

Many EOs had systems of internal committees which enabled members to input into the organization's working and its prioritization of issues. A representative of the British Retail Consortium (BRC) noted that: 
We have a Board [...] made up of around eight or nine members that oversees all of the strategic and operational issues which the organization deals with. We also have a Policy Board which oversees strategy in relation to thematic policy issues and then we have lots of internal committees to deal with specific issues (Interview with BRC representative, 28/06/2017).

Evidence of a governing body existed for 384 bodies (86 per cent of those observed, see Table 2), while data on their size existed for 311(see Table 1).

There was evidence of membership elections to governing bodies for 267 organizations. Eighty-seven EOs provided details of different membership classes, such as an associate membership that offered access to services without voting rights. In some cases, voting rights were associated with member size. However, some EOs with a focus on single social issues had less

TABLE 2

Size of Governing Body

\begin{tabular}{lc} 
No. of members & No. of EOs \\
\hline 1 to 10 & 98 \\
\hline 11 to 20 & 178 \\
\hline $21-30$ & 24 \\
\hline 31 to 40 & 5 \\
\hline $41+$ & 6 \\
\hline
\end{tabular}
democratic structures, and alternative governance models included a non-elected Board of Trustees, as used by the Corporate Alliance against Domestic Violence.

Importantly, interviewees often remarked that the purpose of democratic structures was to create a sense of involvement on the part of members that translated into greater organizational legitimacy. For example, FSB representatives stated that: "We are very competitively priced. We get that through scale. There are a number of members though that will be motivated by the fact that they want to be part of an organization, a movement" (Interview with FSB Wales representative, 18/7/17).

\section{Services provided to members}

The services that EOs provide to their members serve two overlapping purposes. One is to improve members' commitment and provide an incentive for potential members to join (Behrens, 2018). The other purpose is set out by Schmitter and Streeck (1999: 93) as "To become stable and effective organizations, it is essential that they acquire the capacity to procure the compliance of their members with negotiated agreements on matters which otherwise would be under their discretion as private owners."

Areas in which EOs regulate private property rights include investment, vocational training, wage payments exceeding the collective industrial agreement, and competitive practices (Schmitter and Streeck, 1999: 94). While EOs 
in the UK had almost no involvement in investment or the provision of wage payments exceeding collective agreements, they provided services within training, codes of conduct, employment law advisory services and embedding best practice. But do these activities demonstrate that EOs have been procuring the ability to ensure compliance?

Many EOs provided training to their membership, with 309 (69 per cent of those observed) doing so. Activity ranged from the delivery of a small number of technical seminars to large-scale schemes with external accreditation. Accredited training, sourced from organizations such as City and Guilds, was provided by 163 EOs. However, the 309 EOs that provided training generally focused on industry specific issues, with only 107 providing management development. In general, the provision of large-scale training was not a priority for EOs with, for example, a representative of Dairy NI stating that: "Nationally there is a little bit of training done but [...] but if there is training that's needed, the companies would look after that themselves for their own staff" (Interview with Dairy NI representative, 3/6/2015). Overall, the UK's system of vocational training is atomized and operates without significant input from EOs. Such organizations lost institutional positioning within vocational training after 1979, and have been generally unable to compete with large-scale commercial providers and state-run colleges. Instead, EOs activity within training focused on lobbying and the provision of information, with the FSB stating that: "Apprenticeships is a key issue. We've been very actively involved in the Government's apprenticeship reforms particularly around apprenticeship funding reform" (Interview with FSB representative, 2/3/2015).

The provision of member Codes of Conduct linked to competitive practice was common, and EOs sought to establish membership as a mark of quality that members could use to assist business development. Such Codes were used by 232 EOs (52 per cent of those observed) but did not relate to members' role as an employer, with a representative of the Retail Motor Industry Federation (RMIF) noting that its Codes were: "Very commercially focused" (Interview with RMIF representative, 21/06/2017). These commercial Codes tended to be high-level and lightly enforced, lacking comprehensive sanctions to ensure compliance. Virtually all EOs provided other business services, such as conferences, networking, business development, or some advice as to business management issues. EOs often encouraged member companies to use their logos as a mark of quality, with 201 (45 per cent of all those observed) doing so, while 146 (33 per cent of those observed) were active within recruitment and selection. Such activity was generally by providing a vacancy advertising service.

An important service offering linked to employment relations was advice on employment law. Such advice was usually reactive and focused on minimiz- 
ing risks to the employer from individual contracts, and was provided by 208 EOs (47 per cent of those observed). EOs often offered a helpline operated by an outsourced commercial provider, using subscription income to fund access to the service. According to a representative of the Federation of Small Businesses (FSB):

If you look at some of the data around one of our main issues that businesses phone FSB helplines for, it tends to be employment related. Advice, contract related advice, any kind of legal services [...] that's one of the things that most of our members get best value out of (Interview with FSB Wales representative, 18/07/17).

The extent to which such services were seen as being a core offering varied widely, in part due to competition from commercial competitors.

Finally, the small number of EOs that focused on single social issues (employer forums) had a more active approach to employment standards (Gooberman, Hauptmeier, and Heery, 2018b). They provided services that aimed to embed best practice within their members within issues such as Corporate Social Responsibility and equality. For example, the Business Disability Forum's (BDF) membership employed almost 20 per cent of the UK's workforce, and members had access to a benchmarking tool, which the BDF used to encourage members to voluntarily assess and improve employment practices linked to disability (Interview with BDF representative, 7/7/15).

Overall, the manner in which EOs in the UK lacked the ability to shape and influence the behaviour of member companies demonstrated a limited level of strategic autonomy. They had little control over demand for their services, were generally unable to mobilize resources from other environments and had to immediately respond to changes in demand. While EOs were once able to use their institutional positioning to generate services through prioritizing the logic of influence, this logic decayed, although it did not disappear. EOs focused increasingly on self-generated services, some of which were in direct competition with commercial providers such as law and consultancy firms.

\section{Discussion}

Before 1979, national EOs and unions conducted collective bargaining that covered much of the workforce (Brown, 2008). EOs were involved as social partners within economic governance and their representatives were board members of powerful tripartite bodies (Gospel, 2012; Crouch, 1979). Throughout this period, the institutional environment surrounding EOs enabled them to prioritize the logic of influence. They were able to prioritize the logic of influence by demonstrating a credible degree of representativeness over their constituent industry or industries, before securing institutional niches from which they could influence 
employment relations. However, a consistent and prominent theme in our interviews was the impact of the transformation in the UK's employment relations system over recent decades. As the state moved decisively away from post-war corporatism after 1979, collective institutions such as tripartite bodies or those within collective bargaining declined in influence or closed. Activities linked to such institutions decreased in importance even if they did not disappear, while simultaneously the state's regulation of individual employment relationships intensified (Dickens, 2007).

The decline of collective bargaining might have led to greatly decreased levels of employer collective action. However, while the ending of some national agreements did lead to EOs closures and those registered with the Certification Office as bargaining collectively reduced in number, some carried out a successful 'reinvention' after the collapse of their national agreement. Many EOs adapted to the decline of collective bargaining by broadening the provision of member services across employment issues and business development.

While EOs once prioritized the logic of influence through participating in institutional structures, they are now largely external to the UK's formal governance structures, only retaining a foothold in a small number of bodies linked to employment relations. Their relationship with the state within employment relations now focuses on political lobbying. Many EOs identified that lobbying over recent decades gradually broadened from 'narrow' interests towards a broader approach that encompassed employment-related and business issues. Although multi-sectoral EOs naturally sought to satisfy their diverse membership through lobbying across a broad range of topics, single industry EOs focused on issues of relevance to their specific sectors. However, while the industry focus might be narrow, the foci of lobbying were broad across employment relations topics. Despite the importance of lobbying, EOs do not seek generally to obtain resources or establish joint policymaking apparatus with the state. Lobbying instead reflects the fragmented nature of the UK's political economy, with EOs seeking to influence policy across a broad range of issues at both national and devolved levels of governance. EOs finding that their lobbying efforts were not representing members' interests adequately quickly redirected financial and organizational efforts to those activities that were more likely to meet the logic of membership.

In the absence of supporting institutional structures, EOs have prioritized instead the 'logic of membership' through providing member services such as those linked to HRM. While the provision of such services was common, they were generally reactive and procedural. Most EOs advised on how member firms could minimize the risks arising from individual employment relationships, as opposed to seeking to promote best practice standards or approaches. Also, 
democratic governance remained strong throughout EOs despite the lack of any legal requirement to adopt such structures. Democratic governance enabled the membership to participate in decision making and created a sense of ownership and remained an important element of collective employer organization. EOs representatives argued that their ability to attract members depended on enabling members to feel a sense of ownership and control over strategic priorities, as well as being able to access services at competitive rates.

Two tensions were identified earlier as arising from the interaction between the two logics. The first was how the need to retain organizational relevance leads EOs to become 'quasi-authorities' in partnership with the state, with the logic of membership being downgraded in favour of that of influence (Schmitter and Streeck, 1999; Traxler, 2008). However, our data demonstrate that such downgrading has not taken place in the UK. The other tension was how the development of quasi-authorities leads to a downgrading of democratic structures within EOs. However, given that quasi-authorities have not developed in the UK, members' ability to influence EOs decision making through democratic structures has not been reduced. EOs' exclusion from many of the UK's formal governance structures has, however, placed them in a fragile and uncertain position. This exclusion compelled EOs to constantly adjust their structures and operations, similar to other countries where bargaining has decentralized (e.g., Sheldon et al., 2016; You and Barry, 2016).

The overall finding is that external circumstances have led to a change in the degree to which EOs in the UK emphasize both logics within their organizations. While both logics have always been present, the degree to which they are emphasized has transposed. The logic of influence was curtailed due to the changing political economy and these changes prompted employer bodies to focus to a greater degree on the logic of membership.

Further factors have, however, influenced the extent to which EOs focused on the logic of membership. The retention of collective bargaining by a small minority of EOs enabled some continuation of the logic of influence. Nevertheless, bargaining decentralization and dilution as noted, for example, by the Association of Colleges meant that continuation was partial and the salience of the logic of membership grew within such EOs. In other cases, however, the collapse of collective bargaining and the abolition of tripartite structures prompted a more decisive movement towards the logic of membership. For example, the ending of bargaining within automotive retailing and engineering spurred the respective EOs, the Retail Motor Industry Federation and the Engineering Employers Federation, to reorient activities towards the logic of membership. 


\section{Conclusion}

In this study, we analyzed the population of EOs within the UK's liberal market economy to address our research question: What explains the changing role and activities of UK EOs? Our contribution is to apply Schmitter and Streeck's (1999) identification of logics influencing the form and function of employer collective organization to a liberal market economy. We find that although some accounts (e.g., Lang et al., 2008; Traxler, 2007) argued that logics driving influence would be prioritized by EOs over those linked to membership, the opposite has happened in the UK.

EOs once prioritized the logic of influence through their joint governance of institutional collective bargaining and tripartite structures. Marketization and liberalization after 1979, however, gradually removed most of these structures and the literature assumed that EOs had lost their purpose and hence decayed (Baccaro and Howell, 2017; Streeck, 2009). We find that the logic of influence decayed in salience but did not disappear, and EOs focused on the logic of membership to ensure organizational survival. This evolution was driven by institutional change and while the UK has travelled further in terms of liberalization than many other countries, liberalization is a common theme elsewhere (Baccaro and Howell, 2017). Our findings imply that, while the unexpected survival of EOs in the UK was prompted by its transition into an emblematic liberal market economy, liberalization within coordinated market economies may also lead to similar, if far less pronounced, evolution within employer collective bodies (e.g., Behrens and Helfen, 2019).

Changes of EOs activity are not confined to the UK and have been examined by two strands within the 'strange non-death' (Brandl and Lehr, 2016) literature. One strand uses approaches such as resource dependence to examine internal factors such as the motives driving interactions between individual employers and EOs, with less of a focus on external forces (Ibsen and Navrbjerg, 2018; Sheldon et al., 2016; You and Barry, 2016). The other strand uses approaches such as countervailing power to focus on the identification of external forces (Zhu and Nyland, 2016; Gooberman, Hauptmeier, and Heery, 2019b). The advantage of our approach is that it gives equal consideration to both internal and external factors, enabling the analytical gap between the two strands to be bridged by providing clearer linkages between external circumstances and organizational reaction.

Our findings demonstrate that the two logics approach shows utility in the analysis of changing forms of employer collective action across different types of political economy. Recent research across coordinated market economies (e.g., Ibsen and Navrbjerg, 2018; Behrens and Helfen, 2016) and liberal market economies (e.g., 
Sheldon et al., 2016; You and Barry, 2016) highlights patterns of organizational adaptation and survival that show some similarities. Future research might consider the extent to which the logics approach could be used within cross-national studies, exploring the extent to which liberalization and decentralization across liberal and coordinated market economies has driven comparable evolution.

\section{Bibliography}

Ahrne, Göran and Nils Brunsson (2005) "Organizations and Meta-Organizations." Scandinavian Journal of Management, 21, 429-449.

Baccaro, Lucio and Chris Howell (2017) European Industrial Relations since the 1970s: Trajectories of Neoliberal Transformation. Cambridge: Cambridge University Press.

Barry, Michael and Adrian Wilkinson (2011) "Reconceptualising Employer Associations under Evolving Employment Relations: Countervailing Power Revisited." Work, Employment and Society, 25 (1), 149-62.

Behrens, Martin (2018) "Structure and Competing Logics: The Art of Shaping Interests within German Employers' Associations." Socio-Economic Review, 4 (1), 769-789.

Behrens, Martin and Markus Helfen (2019) "Small Change, Big Impact? Organisational Membership Rules and the Exit of Employers' Associations from Multiemployer Bargaining in Germany." Human Resource Management Journal, 29, 51-66.

Behrens, Martin and Markus Helfen (2016) "The Foundations of Social Partnership." British Journal of Industrial Relations, 54 (2), 334-357.

Brandl, Bernd and Alex Lehr (2016) "The Strange Non-Death of Employer and Business Associations: An Analysis of their Representativeness and Activities in Western European Countries." Economic and Industrial Democracy, 1, 22.

Brown, William, Alex Bryson and John Forth (2008) "Competition and the Retreat from Collective Bargaining." Cambridge Working Papers in Economics, Cambridge, Mass., p. 831.

Child, John, Ray Loveridge and Malcom Warner (1973) "Towards an Organizational Study of Trade Unions." Sociology, 7 (1), 71-91.

Crouch, Colin (1979) The Politics of Industrial Relations. London: Fontana.

Crouch, Colin, Wolfgang Streeck, Robert Boyer, Bruno Amable, Peter Hall, and Gregory Jackson (2005) "Dialogue on Institutional Complementarity and Political Economy." Socio-Economic Review, 3, 359-382.

Dickens, Linda, (2007) "The Road is Long: Thirty Years of Equality Legislation in Britain." British Journal of Industrial Relations, 45 (3), 463-494.

Emmenegger, Patrick (2014) The Power to Dismiss: Trade Unions and the Regulation of Job Security in Western Europe. Cambridge: OUP.

Galbraith, John (1952) American Capitalism. Boston, MA: Houghton Mifflin.

Gooberman, Leon, Marco Hauptmeier, and Edmund Heery (2017) "A Typology of Employers' Organisations." Economic and Industrial Democracy. Published online before print.

Gooberman, Leon, Marco Hauptmeier, and Edmund Heery (2018) "Contemporary Employer Interest Representation in the United Kingdom." Work, Employment and Society, 32 (1), 114-132. 
Gooberman, Leon, Marco Hauptmeier, and Edmund Heery (2019a) "The Decline of Employers' Associations in the UK, 1976 to 2014." Journal of Industrial Relations, 61 (1), 11-32.

Gooberman, Leon, Marco Hauptmeier, and Edmund Heery (2019b) "Countervailing Power and the Evolution of Employers' Organisations." Human Resources Management Journal, 29 (1), 82-96.

Gospel, Howard and Edwards, Tony (2012) "Strategic Transformation and Muddling Through: Industrial Relations and Industrial Training in the UK." Journal of European Public Policy, 19 (8), 1229-1248.

Hall, Peter, A. and David Soskice (2001) Varieties of Capitalism: The Institutional Foundations of Comparative Advantage. Oxford England; New York: Oxford University Press.

Heery, Edmund, John Kelly, and Jeremy Waddington (2003) "Union Revitalization in Britain." European Journal of Industrial Relations, 9 (1), 79-97.

House of Commons Committees (2015) "Web page." Retrieved from: https://www.parliament. uk/business/committees/ (December 10, 2015).

Ibsen, Christian Lyhne, and Steen E. Navrbjerg (2019) "Adapting to Survive: The Case of Danish Employers' Organisations." Human Resource Management Journal, 58 (5), 1-15.

Lang, Achim, Karsten Ronit, and Volker Schneider (2008) "From Simple to Complex. An Evolutionary Sketch of Theories of Business Association." In Jürgen Grote, Achim Lang, and Volker Schneider (eds) Organized Business Interests in Changing Environments. The Complexity of Adaptation. Basingstoke: Palgrave Macmillan. p. 17-41.

Martin, Cathie Jo and Duane Swank (2012) The Political Construction of Business Interests: Coordination, Growth and Equality. Cambridge: Cambridge University Press.

Martin, Cathie Jo and Kathleen Thelen (2007) "The State and Co-ordinated Capitalism: Contributions of the Public Sector to Social Solidarity in Post-industrial Societies." World Politics, 60, 1-36.

Olson, Mancur (1965) The Logic of Collective Action: Public Goods and the Theory of Groups. Cambridge, Mass.: Harvard University Press.

Sheldon, Peter, Raoul Nacamulli, Francesco Paoletti, and David E. Morgan (2016) "Employer Association Responses to the Effects of Bargaining Decentralization in Australia and Italy: Seeking Explanations from Organizational Theory." British Journal of Industrial Relations, 54 (1), 160-191.

Simms, Melanie (2017) "Unions and Job Quality in the UK: Extending Interest Representation within Regulation Institutions." Work and Occupations, 44 (1), 47-67.

Schmitter, Philippe and Streeck, Wolfgang (1999) "The Organisation of Business Interests: Studying the Associative Action of Business in Advanced Industrial Societies" MPIfG Discussion Paper, 99 (1), 1-95.

Streeck, Wolfgang (2009) Re-forming Capitalism. Oxford: Oxford University Press.

Streeck, Wolfgang and Kathleen Thelen (2005) "Introduction: Institutional Change in Advanced Political Economies." In Wolfgang Streeck and Kathleen Thelen (eds.), Beyond Continuity. Oxford: Oxford University Press, p. 1-39.

Trade Association Forum (2015) Directory. Retrieved from: http://www.tatoforum.org/Members (December 10, 2015). 
Traxler, Franz (1999) "Gewerkschaften und Arbeitgeberverbande: Probleme der Verbandsbildung und Interessenvereinheitlichung." In Walther Muller-Jentsch, (ed) Konfliktpartnerschaft. Akteure und Institutionen der Industriellen Beziehungen. Munchen: Rainer Hampp Verlag, p. 57-77.

Traxler, Franz (2004) "Employer Associations, Institutions and Economic Change: A Crossnational Comparison." Industrielle Beziehungen, 11, 42-60.

Traxler, Franz (2007) "Introduction." In Franz Traxler and Gerhard Huemer (eds) Handbook of Business Interest Associations, Firm Size and Governance. A Comparative Analytical Approach, London and New York: Routledge, p. 3-9.

Van Wanrooy, Brigid, Helen Bewley, Alex Bryson, John Forth, Stephanie Freeth, Lucy Stokes, and Stephen Wood (2013) The 2011 Workplace Employment Relations Study First Findings. London: Department for Business, Innovation and Skills.

You, Kevin and Michael Barry (2016) "Intra-Industry Competition among Employer Associations: A case Study of the Retail Sector." Labour and Industry: A Journal of the Social and Economic Relations of Work, 26 (2), 120-137.

Zhu, Judith Shuqin and Chris Nyland (2017) "Chinese Employer Associations, Institutional Complementarity and Countervailing Power." Work, Employment and Society, 31 (2), 284-301.

\section{SUMMARY}

\section{The Unexpected Survival of Employer Collective Action in the United Kingdom}

Recent research within employment relations has identified how employer collective organizations continue to thrive in countries featuring different institutional characteristics. In the UK, we identify 447 membership-based Employer Organizations (EOs) active within employment relations and human resource management. The volume of organizations identified prompts our research question: what explains the changing role and activities of UK EOs?

Country-level studies of EOs continuation use a range of theoretical frameworks to analyze how these organizations have adapted to institutional and economic change, but the most effective mode of analysis is debated. Our contribution is to apply Schmitter and Streeck's identification of logics driving the behaviour of employer collective organizations, previously applied to coordinated market economies as defined by the Varieties of Capitalism framework, to the UK's liberal market economy. The article explores the extent to which liberalization prompted new behaviour within UK EOs.

Some studies argue that EOs in coordinated market economies adapt by prioritizing logics driving influence over those linked to membership. We explore how the UK's changing political economy spurred evolution in the application of logics and find that the opposite happened. EOs once used participation within collective bargaining agreements and the governance of tripartite bodies to prioritize the logic of influence but these institutions decayed. It might have been expected that such decay would have caused a withering of EOs but they reconstituted themselves instead. The declining salience of the logic of influence 
prompted employer bodies to focus to a greater degree on the logic of membership by offering a broader range of member-focused services. Our findings indicate that employer collective bodies can react to liberalization with adaptation, not extinction. We also argue that our methodology could shed light on EOs behaviour in North America.

KEYWORDS: employer organizations, collective action, employer interest representation, employment relations, United Kingdom.

\section{RÉSUMÉ}

\section{La survie inattendue de l'action collective des employeurs au Royaume-Uni}

De récentes recherches menées en relations de travail ont montré que les organisations collectives d'employeurs continuent leurs activités dans divers pays présentant des caractéristiques institutionnelles différentes. Au Royaume-Uni, nous avons recensé 447 organisations d'employeurs (OE) actives dans les domaines des relations de travail et de la gestion des ressources humaines. Ce grand nombre d'organisations a inspiré notre question de recherche: Qu'est-ce qui explique l'évolution du rôle et des activités des OE du Royaume-Uni?

Les études menées au niveau national sur le rôle des $O E$ ont eu recours à une gamme de cadres théoriques pour analyser la manière dont ces organisations se sont adaptées dans le temps aux changements institutionnels et économiques, mais, le mode d'analyse le plus efficace fait toujours l'objet de débats. Dans cet article, notre contribution consiste à appliquer, à l'économie de marché libérale du Royaume-Uni, le cadre de Schmitter et Streeck qui identifie les logiques sousjacentes régissant le comportement des $\mathrm{OE}$, cela en utilisant le même cadre appliqué aux économies de marché coordonnées, telles que définies dans le cadre des études sur les "variétés du capitalisme ". L'article regarde dans quelle mesure la libéralisation a provoqué un nouveau comportement au sein des OE.

Certaines études ont soutenu que, dans les économies de marché coordonnées, les OE vont s'adapter en accordant la priorité aux logiques liées au membership. Nous explorons comment l'évolution de l'économie politique britannique a entraîné une évolution dans l'application des logiques d'adaptation des OE et constatons que c'est plutôt l'inverse qui s'est produit. Par le passé, les OE privilégiaient plutôt une logique d'influence faisant appel à la participation des membres dans le cadre des négociations collectives face aux syndicats ainsi que pour œuvrer au sein d'organismes institutionnels tripartites, mais ces institutions se sont effondrées. On aurait pu s'attendre à ce que cette dégradation se traduise par le dépérissement des $\mathrm{OE}$, mais elles se sont plutôt réorganisées. La diminution de l'importance de la logique d'influence a incité les organismes d'employeurs à se concentrer davantage sur la logique du membership en proposant une gamme plus large de services destinés aux membres. Nos résultats indiquent que les $O E$ peuvent réagir à la libéralisation par une adaptation, cela afin d'éviter l'extinction. Enfin, nous 
croyons que notre méthodologie pourrait servir à éclairer le comportement des $\mathrm{OE}$ en Amérique du Nord.

MOTS-CLÉs: organisations d'employeurs, action collective, représentation des intérêts des employeurs, relations de travail, Royaume-Uni.

\section{RESUMEN}

\section{La inesperada sobrevivencia de la acción colectiva de los empleadores en el Reino Unido}

Investigaciones recientes dentro del campo de las relaciones laborales han identificado cómo las organizaciones colectivas de empleadores continúan prosperando en países con características institucionales diferentes. En el Reino Unido identificamos 447 organizaciones de empleadores (OE) basadas en la membresía que son activas en el campo de las relaciones de empleo y en el de la gestión de recursos humanos. El volumen de organizaciones identificadas incita nuestra pregunta de investigación: ¿Qué es lo explica el cambio de rol y de actividades de las OE del Reino Unido?

Los estudios a nivel de país sobre la continuación de las OE utilizan una serie de marcos teóricos para analizar cómo estas organizaciones se han adaptado al cambio institucional y económico, pero se debate el modo de análisis más eficaz. Nuestra contribución consiste en utilizar la identificación de Schmitter y Streeck de las lógicas que conducen el comportamiento de las organizaciones colectivas de empleadores, previamente aplicadas a las economías de mercado coordinadas y definidas según el enfoque de Variedades del Capitalismo, para aplicarla a la economía liberal de mercado del Reino Unido. El artículo explora en qué medida la liberalización provocó un nuevo comportamiento dentro de las OE del Reino Unido.

Algunos estudios sostienen que las OE en las economías de mercado coordinadas se adaptan dando prioridad a las lógicas que conducen a la influencia en detrimento de aquellas vinculadas a la membrecía. Exploramos como la cambiante economía política del Reino Unido estimuló la evolución en la aplicación de las lógicas y descubrimos que sucedió lo contrario. Las OE utilizaron antes la participación en los acuerdos de negociación colectiva y la gobernanza de los organismos tripartitos para priorizar la lógica de la influencia, pero estas instituciones decayeron. Se podría haber esperado que tal decaimiento hubiera provocado un debilitamiento de las $\mathrm{OE}$, pero en su lugar se reconstituyeron. La importancia decreciente de la lógica de influencia llevó a los organismos de los empleadores a centrarse en mayor medida en la lógica de membrecía al ofrecer una gama más amplia de servicios centrados en los miembros. Nuestros resultados indican que los organismos colectivos de empleadores pueden reaccionar a la liberalización con la adaptación, no con la extinción. También argumentamos que nuestra metodología podría ser utilizada para esclarecer el comportamiento de las OE en América del Norte.

PALABRAS CLAVES: Organizaciones de empleadores, acción colectiva, representación de intereses del empleador, relaciones de empleo, Reino Unido. 